\title{
LAYANAN BIMBINGAN PRIBADI SOSIAL UNTUK MENGEMBNGKAN RASA PERCAYA DIRI SISWA TUNAGRAHITA SLB MANDARA KOTA KENDARI
}

\author{
oleh: \\ Harlin Yusuf ${ }^{1)}$, Sumarlin ${ }^{2)}$, Hamdiansah ${ }^{3)}$ \\ Dosen Jurusan PG-PAUD ${ }^{1)}$, Dosen Jurusan Bimbingan dan Konseling ${ }^{2)}$ 3) \\ Fakultas Keguruan dan Ilmu Pendidikan Universitas Halu Oleo \\ Email: harlinyusuf88@gmail.com
}

\begin{abstract}
ABSTRAK
Penelitian ini bertujuan untuk menyusun sebuah produk pengembangan berupa model layanan bimbingan pribadi sosial untuk mengembangkan rasa percaya diri siswa tunagrahita. Tujuan jangka panjang penelitian ini adalah guru Sekolah Luar Biasa (SLB) dapat menggunakan produk pengembangan yang telah disusun sebagai salah satu teknik dalam menyelengarakan layanan bimbingan pribadi sosial, terutama pada kegiatan yang bertujuan meningkatkan kepercayaan diri siswa tunagrahita. Hasil yang ditargetkan dalam penelitian ini adalah mengembangkan rasa percaya diri siswa tunagrahita yang menjadi subjek penelitian dengan pemberian layaan bimbingan pribadi sosial. Indikator kepercayaan diri subjek penelitian yang diukur adalah a) r a s a optimis siswa tunagrahita, b) kemampuan siswa dalam berpikir positif, c) kemandirian siswa tunagrahita, d) penilaian diri, dan e) toleransi. Jenis penelitian ini adalah penelitian eksperimen dengan jenis pra-eksperimen. Oleh karena itu, penelitian ini hanya memberikan perlakuan kepada satu kelompok eksperimen tanpa menggunakan kelompok kontrol sebagai pembanding. Desain penelitian ini menggunakan one group pre-test and post-test design yang meliputi tiga langkah pelaksanaan, yaitu: 1) pelaksanaan pre-test 2) pelaksanaan perlakuan atau eksperimen, dan 3) pelaksanaan post-tes untuk mengukur hasil atau dampak dari perlakuan. Indikator keberhasilan layanan bimbingan pribadi sosial jika terjadi perkembangan kepercayaan diri siswa tunagrahita secara signifikan yang akan diketahui melalui pembandingan skor pretest dan post test subjek penelitian. Kepercayaan diri siswa tunagrahita sebelum mendapatkan layanan bimbingan pribadi sosial (pre-test) mencapai rata-rata 39\%, tetapi setelah mendapatkan layanan bimbingan pribadi sosial (post-test) rasa kepercayaan diri siswa tunagrahita mengalami perkembangan dengan rata-rata $49 \%$. Jadi perkembangan rasa percaya diri siswa tunagrahita mencapai $10 \%$.
\end{abstract}

Kata Kunci: Bimbingan Pribadi Sosial, Kepercayaan Diri, dan Tunagrahita 


\title{
SOCIAL PERSONAL GUIDANCE SERVICES TO DEVELOP THE CONFIDENCE OF THE TUNAGRAHITA STUDENTS SLB MANDARA KENDARI CITY
}

\begin{abstract}
This study aims to compile a product of development in the form of a model of social personal guidance services to develop students' mental retardation self-confidence. The long-term goal of this study is that special school teachers can use development products that have been developed as one of the techniques for holding social personal guidance services, especially in activities aimed at increasing the self-confidence of mentally disabled students. The targeted results in this study are to develop the confidence of retarded students who are the subjects of research by providing social personal guidance services. Indicators of self-confidence measured by research subjects are a) optimism for mentally retarded students, $b$ ) students' ability to think positively, $c$ ) independence of mentally retarded students, d) self-assessment, and e) tolerance. This type of research is experimental research with pre-experimental type. Therefore, this study only gave treatment to one experimental group without using a control group as a comparison. This research design uses one group pre-test and post-test design which includes three steps of implementation, namely: 1) the implementation of pre-test 2) the implementation of the treatment or experiment, and 3) the implementation of the posttest to measure the results or the impact of the treatment. Indicators of success of social personal guidance services if there is a significant development of self-retarded students' confidence that will be known through comparing the pretest and post test scores of research subjects. The mental disability of mentally retarded students before getting social personal guidance services (pre-test) reached an average of 39\%, but after getting social personal guidance services (post-test) the self-confidence of mentally retarded students experienced an average growth of $49 \%$. So the development of mental retardation students reach $10 \%$.
\end{abstract}

Keywords: Social Personal Guidance, Self Confidence, and Developmental Retardation

\section{PENDAHULUAN}

Kepercayaan diri merupakan modal utama peserta didikuntuk mencapai kesuksesan. Peserta didik yang mempunyai kepercayaan diri berarti peserta didik tersebut sanggup, mampu, dan meyakini dirinya dapat mencapai prestasi maksimal. Kepercayaan diri menurut Lauster (2008:4) merupakan suatu sikap atau kewajiban atas kemampuan diri sendiri, sehingga dalam tindakan-tindakannya tidak terlalu cemas, merasa bebas untuk melakukan hal-hal yang sesuai keinginan dan tanggung jawab atas perbuatannya, sopan dalam berinteraksi dengan orang lain, memiliki dorongan prestasi serta dapat mengenal kelebihan dan kekurangan diri sendiri. Lauster menggambarkan bahwa orang yang mempunyai kepercayaan diri memiliki ciri-ciri tidak mementingkan diri sendiri (toleransi), tidak membutuhkan dorongan orang lain, optimis dan gembira.

Beberapa ciri atau karakteristik peserta didik yang kurang percaya diri, di antaranya adalah: berusaha menunjukkan sikap konformis, semata- 
mata demi mendapatkan pengakuan dan penerimaan kelompok; menyimpan rasa takut/kekhawatiran terhadap penolakan; sulit menerima realita diri (terlebih menerima kekurangan diri) dan memandang rendah kemampuan diri sendiri namun di lain pihak memasang harapan yang tidak realistik terhadap diri sendiri, pesimis, mudah menilai segala sesuatu dari sisi negatif; takut gagal, sehingga menghindari segala resiko dan tidak berani memasang target untuk berhasil; cenderung menolak pujian yang ditunjukkan secara tulus (karena undervalue diri sendiri); selalu menempatkan/memposisikan diri sebagai yang terakhir, karena menilai dirinya tidak mampu; mempunyai external locus of control (mudah menyerah pada nasib, sangat tergantung pada keadaan dan pengakuan/penerimaan serta bantuan orang lain) (Fatimah 2010:150).

Dasar dari motivasi untuk memperoleh minat belajar peserta didik tunagrahita adalah kepercayaan diri yang tinggi.Seseorang yang mendapatkan ketenangan dan kepercayaan diri harus memiliki motivasi yang tinggi untuk terus tumbuh serta mampu mengubah masalah menjadi tantangan. Sebagai contoh dari orang yang memiliki tingkat kepercayaan yang tinggi adalah Napoleon Bonaparte. Napoleon Bonaparte tinggi badannya hanya mencapai lima kaki dan dua inci. Tak satu haripun ia merasa pendek dan kerdil di hadapan lawan-lawannya dan pasukannya. Namun, melihat dirinya menjadi raksasa di antara laki-laki lainnya, meskipun sebenarnya tidak demikian. Kepercayaan diri dan kebesaran hati membuatnya bersikap, bergaul, bersama orang lain dengan penuh percaya diri dan kemampuan menghadapi segala kesulitan dengan kepercayaan diri yang besar.

Layanan bimbingan pribadi sosial merupakan bagian dari pendidikan lingkungan sekolah yang diharapkan dapat memberikan kontribusi untuk memberikan bantuan kepada peserta didik dalam mengaktualisasikan potensinya. Dalam hal ini bimbingan sosial pribadi adalah upaya yang dilakukan konselor untuk mengatasi berbagai permasalahan siswa yang diantaranya adalah kepercayaan diri peserta didik. Supaya layanan bimbingan sosial pribadi dapat mengatasi berbagai permasalahan yang dialami oleh peserta didik, khususnya peserta didik tunagrahita, maka pelaksanaannya harus berdasarkan pada kebutuhan dan permasalahan peserta didik yang dibimbing.

\section{A. Konsep Dasar Tunagrahita}

\section{Pengertian Tunagrahita}

Tunagrahita termasuk dalam golongan anak berkebutuhan khusus (ABK). Pendidikan secara khusus untuk penyandang tunagrahita lebih dikenal dengan sebutan sekolah luar biasa (SLB). Pengertian tunagahita pun bermacam-macam.Tunagrahita ialah istilah yang digunakan untuk menyebut anak yang mempunyai kemampuan intelektual di bawah rata-rata. Istilah lain untuk tunagrahita ialah sebutan untuk anak yang memiliki penurunan kemampuan atau berkurangnya kemampuan dalam segi kekuatan, nilai, kualitas, dan kuantitas.

Salah satu pengertian yang dapat menggambarkan keadaan anak tunagrahita adalah dari American Association on Mental Deficiency(AAMD) tahun 1973. 
Batasan tersebut sebagai berikut: "Mental retardaction refers to significantly subaverage general Intellectual functioning resulting in or adaptive behavior and manifested during the developmental period". Artinya, ketunagrahitaan mengacu pada fungsi intelektual umum yang secara nyata (signifikan) berada di bawah ratarata (normal) bersamaan dengan kekurangan dalam tingkah laku penyesuaian diri dan semua ini berlangsung (termanifestasi) pada masa perkembangannya (Halahan \& Kauffman, 1988:46).

\section{Penyebab Terjadinya Tunagrahita}

Peserta didik yang memang ketunagrahitaannya cukup signifikan penyebabnya biasanya dihubungkan dengan waktu terjadinya ketunagrahitaan: prenatal (sebelum lahir), perinatal (pada waktu atau beberapa saat setelah lahir), atau postnatal (setelah lahir). Contoh-contoh berikut menggambarkan jenis-jenis kondisi yang dapat mengakibatkan ketunagrahitaan dan hubungannya dengan ilmu pengetahuan tentang kelainan ini.

\section{Karakteristik Tunagrahita}

\section{Karakteristik Belajar}

Paling umum untuk menentukan karakteristik seseorang dengan ketunagrahitaan adalah adanya kelainan dalam fungsi kognitif. Para peneliti biasanya bukan berhubungan dengan kemampuan intelektual orang tersebut, tetapi pada dampak rendahnya IQ yang dimiliki pada kemapuan belajar individu, perolehan informasi, proses informasi, dan penerapan pengetahuan dalam berbagai seting baik sekolah maupun masyarakat. Para ilmuwan belum memahami secara utuh rentang rumitnya proses belajar pada manusia.

\section{Perhatian}

Perhatian, merupakan konsep yang multi dimensi, memainkan peranan yang penting dalam belajar. Banyak kesulitan pada individu dengan ketunagrahitaan disebabkan oleh adanya kekurangan perhatian. Sebelum belajar suatu tugas tertentu, seseorang harus mampu memikirkan beberapa sifat penting yang berhubungan dengan tugas tersebut.Tomporowski dan Tinsley (1997) membuat suatu teori bahwa individu dengan ketunagrahitaan mengalami kesulitan menfokuskan perhatian, mempertahankannya, dan memilih berbagai rangsangan yang sesuai.Mereka juga kurang perhatian terhadap tugas.Hal itu dapat terjadi karena anak-anak dengan ketunagrahitaan menunjukkan tugastugas belajar tertentu dengan jelek disebabkan karena mereka tidak mampu menghubungkan aspek-aspek atau dimensi-dimensi yang relevan dalam suatu masalah.

\section{Daya Ingat}

Daya ingat atau memori, sebagai komponen penting dari belajar, sering mengalami kelainan pada anak-anak dengan ketunagrahitaan.Secara umum dapat dikatakan, bahwa tambah berat ketunagrahitaan, tambah besar kurangnya daya ingat (Drew \& Hardman, 2004).

\section{Kinerja Akademik}

Seperti mungkin anda antisipasi, peserta didik dengan ketunagrahitaan menghadapi kesulitan dalam pekerjaan akademis. Umumnya, kekurangan ini terlihat dalam berbagai bidang pengajaran, tatapi membaca merupakan 
bidan yang paling lemah, khususnya membaca oemahaman (Katims, 2000). Peserta didik dengan ketunagrahitaan juga lemah dalam berhitung, tapi kinerja mereka lebih dari usia mentalnya (Drew \& Hardman, 2004).

\section{Motivasi}

Beberapa siswa dengan ketunagrahitaan mempunyai kesamaan karakteristik dengan siswa berkesulitan belajar.Mereka mengalami masaah dalam motivasi dan kurang berdaya dalam belajar, dan kecenderungan untuk mudah dalam belajar bukan ebagai akibat dari adanya frustasi terhadap tugas yang harus dikerjakannya.Hal itu muncul kadang-kadang sebagai akibat dari adanya bantuan berlebihan yang diberikan oleh guru atau teman-teman sekelasnya. Beberapa siswa dengan ketunagrahitaan kemudian terbiasa bahwa jika dia diam sebentar, seseorang akan segera membantunya.

\section{Karakteristik Sosial dan Perilaku}

Greenspan dan Love (1997) mengemukakan bahwa berhasil atau gagalnya peserta didik dengan ketunagrahitaan yang di tempatkan di kelas umum sering ditentukan oleh keterampilan sosialnya.

\section{Pembelajaran Anak Tunagrahita}

Membuat perencanaan untuk generalisasi dan membaut konsepkonsep yang abstrak menjadi lebih konkrit merupakan beberapa strategi penting dalam pendidikan bagi anak dengan ketunagrahitaan. Seperti halnya beberapa peserta didik memerlukan kurikulum kecakapan hidup dan akademik fungsional, sementara yang lainnya mengikuti kurikulum pendidikan umum. Adanya beberapa pilihan tersebut menggambarkan adanya praktek pembelajaran yang direkomendasikan.Yang penting juga untuk diperhatikan adalah penggunaan strategi lainnya seperti sudah dikemukakan sebelumnya, seperti pembelajaran langsung dan intervensi perilaku, serta perencanaan perilaku di sekolah yang lebih luas. Ketika memikirkan tentang pembelajaran bagi anak-anak dengan ketunagrahitaan, hal pentin yang perlu diingat adalah mengimplementasikan prinsip-prinsip pola umum untuk pembelajaran, membangun kesempatan dalam pembelajaran selama perencanaan akan membuat semua anak mampu untuk belajar dan berpartisipasi (Hitcock, Meyer, Rose, \& Jackson. 2002).

\section{Analisis Tugas}

Strategi pembelajaran untuk meyakinkan bentuk belajar yang sangat sistematis disebut analisis tugas. Yang perlu diingat bahwa peserta didik dengan ketunagrahitaan memerlukan langkah-langkah praktis untuk melakukan suatu tugas lebih dari peserta didik yang lainnya.

\section{Pembelajaran dengan Menggunakan Teman Sebaya.}

Pendekatan dalam pembelajaran dengan menggunakan teman sebaya lainnya adalah tutor teman sebaya yang efektif untuk siswa dengan ketunagrahitaan (Spencer \& Balboni, 2003). Tutor teman sebaya merupakan satu pendekatan pembelajaran dimana siswa berteman, disiapkan bahan-bahan pembelajaran yang akan mereka pelajari, dan diharapkan adanya saling membantu antara satu dan yang lainnya sesuai dengan tujuan belajar. 


\section{B. Konsep Dasar Percaya Diri}

\section{Pengertian Percaya Diri}

Kepercayaan diri adalah satu di antara aspek-aspek kepribadian yang penting dalam kehidupan manusia. Alfred Adler meneliti mengenai rasa rendah diri.Ia mengatakan bahwa kebutuhan yang paling penting adalah kebutuhan akan rasa percaya diri dan rasa superioritas (Lauster, 2008: 13).

Kepercayaan diri yang tinggi sebenarnya hanya merujuk pada adanya beberapa aspek dari kehidupan individu tersebut dimana ia merasa memiliki kompetensi, yakin, mampu, dan percaya bahwa dia bisa karena didukung oleh pengalaman, potensi aktual, dan prestasi harapan yang realistik terhadap diri sendiri.

\section{Faktor Penyebab Percaya Diri}

Faktor-faktor yang mempengaruhi kepercayaan diri pada seseorang menurut Hakim (2002:121) sebagai berikut:
a. Lingkungan keluarga
b. Pendidikan Formal
c. Pendidikan non Formal

\section{Karakteristik Percaya Diri}

Kepercayaan diri individu mempunyai karakteristik tersendiri yang membedakan mereka dari individu yang tidak memiliki rasa percaya diri. Individu yang percaya diri mempercayai kemampuan dirinya sendiri, mempunyai rasa mengendalikan hidupnya, mempercayai bahwa, karena beberapa alasan, mereka dapat melakukan apa yang mereka harapkan, rencanakan, dan inginkan. Mereka mempunyai keinginan yang realistik. Mereka akan mengambil resiko tidak diterima oleh orang lain karena mereka secara umum mempercayai kemampuan mereka sendiri. Mereka cenderung dapat menerima diri mereka sendiri, mereka tidak merasa harus menjadi konformis hanya untuk diterima orang lain.

\section{Cara MengembangkanPercaya Diri}

Fatimah (2010:150) menyatakan bahwa untuk menumbuhkan kepercayaan diri yang proporsional maka individu harus memulainya dari dalam diri sendiri. Beberapa cara yang dapat dilakukan individu yang dapat dilakukan dalam menanggulangi krisis kepercayaan diri sebagai berikut:

1. Evaluasi diri secara obyektif

2. Beri penghargaan yang jujur terhadap diri

3. Positive thinking

4. Gunakan self-affirmation

5. Berani mengambil resiko

6. Belajar mensyukuri dan menikmati rahmat Tuhan

7. Menetapkan tujuan yang realistic

\section{Layanan Bimbingan Pribadi Sosial}

\section{Bimbingan Pribadi Sosial}

Bimbingan pribadi sosial merupakan proses bantuan yang menyangkut keadaan batinnya sendiri, kejasmanian sendiri, dan menyangkut hubungan dengan orang lain (W.S Winkel, 1997:142) Bimbingan ini dimaksudkan agar individu mampu berhubungan baik dengan diri sendiri dan orang lain sepanjang perjalanan hidupnya.

\begin{tabular}{lllr}
\multicolumn{2}{c}{ Bimbingan } & pribadi sosial \\
diarahkan untuk & \multicolumn{2}{r}{ memantapkan } \\
kepribadian & dan & mengembangkan \\
kemampuan & peserta & didik dalam \\
menangani & \multicolumn{3}{c}{ masalah-masalah } \\
dirinya.Bimbingan & \multicolumn{2}{c}{ ini merupakan } \\
pelayanan yang mengarah peada
\end{tabular}


pencapaian pribadi yang baik dengan memperhatikan keunikan karakteristik pribadi serta ragam permasalahan yang dialami oleh peserta didik.

Bimbingan pribadi sosial sendiri biasanya diberikan melalui penciptaan lingkungan yang kondusif, interaksi pendidikan yang akrab, mengembangkan pemahaman diri dan sikap-sikap yang positif serta keterampilan-keterampilan pribasi sosial yang tepat.Pada dasarnya, fungsi bimbingan tidak hanya untuk mengatasi permasalahan yang dihadapi oleh individu tetapi juga berfungsi untuk mencegah dan mengembankan.

\section{Tujuan Bimbingan Pribadi Sosial}

Bimbingan pribadi sosial memiliki beberapa tujuan. Tujuan tersebut diperjelas oleh Syamsu Yusuf (2006:14) yang mengatakan bahwa tujuan yang ingin di capai dari bimbingan pribadi sosial adalah membantu siswa untuk dapat mengamalkan nilai-nilai keimanan dan ketaqwaan kepada Tuhan Yang Maha Esa, mampu memahami dan menerima kelebihan dan kekurangan diri, bersikap respek terhadap sesame dan diri sendiri, memiliki kemampuan melakukan pilihan yang sehat, mengambil keputusan secara efektif, memiliki rasa tanggung jawab, memiliki kemampuan berinteraksi sosial dan dapat menyelesaikan konflik pribadi maupun sosial.

\section{METODE PENELITIAN}

\section{Jenis Penelitian}

Jenis penelitian ini adalah penelitian eksperimen dengan jenis praeksperimen. Oleh karena itu, penelitian ini hanya memberikan perlakuan kepada satu kelompok eksperimen tanpa menggunakan kelompok kontrol sebagai pembanding. Desain penelitian ini menggunakan one group pretest and post-test design yang meliputi tiga langkah pelaksanaan, yaitu: 1) pelaksanaan pre-test 2) pelaksanaan perlakuan atau eksperimen, dan 3) pelaksanaan posttes untuk mengukur hasil atau dampak dari perlakuan. Secara skematis dapat dilukiskan dalam bagan berikut ini:

Tabel 1. Skema Penelitian

\begin{tabular}{ccc}
\hline Pre-test & Treatment & $\begin{array}{c}\text { Post-test } \\
\mathrm{O}_{1}\end{array}$ \\
\hline
\end{tabular}

SLB Mandara Kota Kendari pada semester ganjil tahun pelajaran 2019/ 2020. Penelitian dilaksanakan selama 2 bulan yakni pada bulan Oktober - November 2019 dengan penyelenggaraan layanan sebanyak 5 kali pertemuan dengan durasi waktu selama 2 X 45 menit.

\section{Subjek Penelitian}

Subjek dalam penelitian berjumlah 6 orang siswa tunagrahita yang duduk di kelas VI. Alasan memilih subjek tersebut adalah sebagai berikut:

1. SLB Mandara memiliki siswa tunagrahita mulai dari kelas I-VI tetapi kelas I-V masih kurang aktif dalam mengikuti proses pembelajaran di kelas, mereka masih banyak yang jarang masuk mengikuti proses belajar mengajar di kelas dengan baik.

2. SLB Mandara memiliki siswa tunagrahita tingkat SMP dan SMA tetapi mereka berdasarkan hasil wawancara dengan guru yang ada 
di sana sudah memiliki kepercayaan diri yang baik sehingga difokuskan pada siswa tunagrahita tingkat SD.

3. Subjek penelitian setuju untuk terlibat dan mau bekerja sama selama mengikuti pemberian layanan.

4. Tidak sedang mendapat intervensi bimbingan layanan lainnya.

5. Terdaftar sebagai siswa aktif di SLB Mandara Kota Kendari.

\section{Teknik Pengumpulan Data}

Teknik yang digunakan dalam pengumpulan data yang berkaitan dengan layanan bimbingan pribadi sosial untuk mengembangkan kepercayaan diri peserta didik tunagrahita adalah pertama observasi, observasi dalam penelitian ini adalah observasi terbuka, yakni melakukan observasi atau pengamatan langsung. Kedua wawancara yang digunakan untuk menggali data tentang kondisi awal peserta didik tunagrahita. Adapun wawancara dilakukan oleh peneliti kepada guru subjek. Angket (kuesioner), yang digunakan sebagai alat pengumpul data yang dikembangkan berdasarkan skala kepercayaan diri peserta didik tunagrahita yang dikembangjan oleh Gie (1995) dengan beberapa adaptasi sesuai kebutuhan peneliti. Angket yang telah dibuat diuji validasikan oleh pakar. Bentuk angket tertutup format force choice dengan alternative pernyataan hanya 5 pilihan yaitu: $\mathrm{SL}=$ Selalu, $\mathrm{SR}=$ Sering, $\mathrm{KD}=$ Kadangkadang, $\mathrm{JR}=$ Jarang, $\mathrm{TDP}=$ Tidak pernah, masing-masing pernyataan ditentukan skor ; $\mathrm{SL}=4, \mathrm{SR}=3, \mathrm{KD}=$ 2 , $\mathrm{JR}=1$, dan $\mathrm{TDP}=0$. Apabila ada pernyataan negatif maka pemberian skor dibalik. Skor pernyataan negatif yaitu $\mathrm{SL}=0, \mathrm{SR}=1, \mathrm{KD}=2, \mathrm{JR}=3$, dan $\mathrm{TDP}=4$.

Data yang telah dikumpulkan kemudian dianalisis menggunakan analisis deskriptif persentase untuk menjelaskan hasil perhitungan skor pre-test (tes awal) dan post-test (tes akhir). Teknik analisis deskriptif persentase adalah teknik analisis data yang dilakukan untuk mengetahui gambaran tingkat kepercayaan diri siswa sebelum diberikan layanan bimbingan pribadi sosial dan setelah diberikan layanan bimbingan pribadi sosial. Adapun kategori tingkat kecerdasan emosional siswa dapat dilihat melalui tabel berikut:

Tabel 2. Kategori Kepercayaan Diri Siswa

\begin{tabular}{cc}
\hline Interval skor & Kategori \\
\hline$X>50$ & Tinggi \\
\hline$X<50$ & Rendah \\
\hline
\end{tabular}

\section{HASIL DAN PEMBAHASAN}

\section{Hasil Penelitian}

\section{Deskripsi Hasil Pre Tes Skala Kepercayaan Diri Siswa}

Gambaran kepercayaan diri siswa tunagrahita sebelum diberikan layanan bimbingan pribadi sosial yang diberikan kepada 6 subjek penelitian. Selanjutnya skor pre test tersebut dikonversikan ke dalam beberapa kategori untuk mengukur tingkat kepercayaan diri siswa tunagrahita. Analisis deskriptif terhadap kepercayaan diri siswa dapat dilihat melalui tabel berikut ini. 
Tabel 3. Skor Pre Test Kepercayaan Diri Siswa Tunagrahita

\begin{tabular}{ccccc}
\hline No & Responden & Skor & \% & Kategori \\
\hline 1 & R01 & 45 & 34 & Rendah \\
\hline 2 & R02 & 58 & 44 & Rendah \\
\hline 3 & R03 & 53 & 40 & Rendah \\
\hline 4 & R04 & 54 & 41 & Rendah \\
\hline 5 & R05 & 52 & 39 & Rendah \\
\hline 6 & R06 & 47 & 35 & Rendah \\
\hline \multicolumn{2}{r}{ Rata-rata } & $\mathbf{5 2}$ & $\mathbf{3 9}$ & Rendah \\
\hline
\end{tabular}

Berdasarkan tabel tersebut, terlihat bahwa seluruh siswa tunagrahita tersebut memiliki kepercayaan diri yang rendah. Seluruh subjek tidak ada yang memiliki presentase kepercayaan diri di atas $50 \%$, dalam hal ini seluruh siswa tersebut sangat membutuhkan layanan bimbingan untuk mengembangkan rasa percaya diri mereka.

\section{Deskripsi Hasil Post Tes Skala Kecerdasan Emosional Siswa}

Gambaran Kepercayaan diri siswa tunagrahita setelah mendapatkan layanan bimbingan pribadi sosial (skor post test) dilihat dari skor hasil pengisian skala kepercayaan diri yang diberikan kepada 6 subjek penelitian. Selanjutnya skor post test tersebut dikonversikan ke dalam beberapa kategori untuk mengukur tingkat kepercayaan diri mereka. Analisis deskriptif terhadap kepercayaan diri siswa tunagrahita dalap dilihat melalui tabel berikut ini.

Tabel 3. Skor Post Test Kepercayaan Diri Siswa Tunagrahita

\begin{tabular}{ccccc}
\hline No & Responden & Skor & $\mathbf{\%}$ & Kategori \\
\hline 1 & R01 & 53 & 40.15 & Rendah \\
\hline 2 & R02 & 72 & 54.5 & Tinggi \\
\hline 3 & R03 & 65 & 49.24 & Rendah \\
\hline 4 & R04 & 68 & 51.5 & Tinggi \\
\hline 5 & R05 & 70 & 53 & Tinggi \\
\hline 6 & R06 & 59 & 44.69 & Rendah \\
\hline Rata-rata & $\mathbf{6 5}$ & $\mathbf{4 9}$ & Rendah \\
\hline
\end{tabular}

Berdasarkan tabel 3 tersebut, terlihat bahwa 3 orang subjek penelitian memiliki skor kepercayaan diri pada kategori tinggi, sedangkan 3 subjek siswa tunagrahita lainnya masih memiliki kepercayaan diri yang rendah. Layanan bimbingan pribadi sosial mampu mampu mengembangkan rasa percaya diri siswa tunagrahita SLB Mandara Kota Kendari.

\section{Perbandingan Skor Pre Test dan Post Test Siswa Tunagahita}

Berdasarkan hasil analisis data, dapa terlihat bahwa secara keseluruhan terdapat peningkatan skor kepercayaan diri pada seluruh subjek penelitian meskipun ketika dikonversi kedalam kategori, masih terdapat subjek penelitian yang kategori kepercayaan dirinya rendah. Perbandingan skor dan kategori kepercayaan diri subjek penelitian dapat dilihat melalui tabel berikut:

Tabel 4. Skor Pre Test dan Post tes Kepercayaan Diri Siswa Tunagrahita

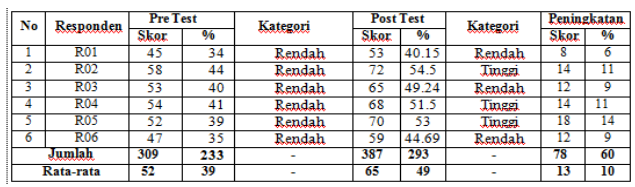

Tabel tersebut menggambarkan kepercayaan diri siswa tunagrahita. Seluruh siswa tunagrahita mengalami perkembangan kepercayaan diri setelah mendapatkan layanan bimbingan pribadi sosial selama 5 minggu di sekolah. Pada kegiatan pre test menunjukan hasil kepercayaan diri siswa tunagrahita rendah semuanya, tetapi setelah mengikuti layanan bimbingan pribadi sosial ada 3 orang siswa tunagrahita yang mengalami rasa percaya diri yang tinngi. Julah rata-rata keprcayaan diri siswa tunagrahita sebelum mendapatkan layanan bimbingan pribadi sosial yaitu 39\% sedangkan setelah memperoleh layanan bimbingan pribadi 
soial nilai rata-rata kepercayaan diri siswa tunagrahita berkembang menjadi 49\%. Jadi perkembangan keprcayaan diri siswa tunagrahita sebelum dan sesudah mendapatkan layanan bibmingan pribadi sosial yang $10 \%$.

\section{KESIMPULAN DAN SARAN}

\section{Kesimpulan}

1. Sebelum pemberian layanan bimbingan pribadi sosial, kepercayaan diri siswa tunagrahita SLB Mandara Kota Kendari masih tergolong rendah. Adapun rata-rata kepercayaan diri siswa tunagrahita sebelum mendapatkan layanan bimbingan pribadi sosial berada dalam rata-rata 233 atau hanya sebesar $39 \%$.

2. Setelah pemberian layanan bimbingan pribadi sosial, skor kepercayaan diri subjek penelitian yang memiliki tingkat kepercayaan diri rendah mengalami perkembangan sampai $10 \%$ sehingga rasa percaya diri siswa tunagrahita setelah mendapatkan layanan bimbingan pribadi sosial berada dalam rata-rata 293 atau $49 \%$.

\section{Saran}

1. Guru Sekolah Luar Biasa (SLB) dapat menjadikan layanan bimbingan pribadi sosial sebagai salah satu alternatif layanan dalam membentuk kepercayaan diri siswa tunagrahita.

2. Persoalan kepercayaan diri perlu mendapat perhatian khusus sebagai komponen kepribadian yang harus ada dalam diri peserta didik sebagai bagian dari upaya membentuk sumber daya manusia yang unggul dan berkepribadian.

3. Layanan bimbingan pribadi sosial perlu dikemas dalam bentuk yang lebih inovatif agar mampu meningkatkan antusias peserta didik selama mengikuti kegiatan layanan.

\section{DAFTAR PUSTAKA}

Angelis, Barbara. (2003). Percaya Diri Sumber Sukses dan Kemandirian. Jakarta: Gramedia Pustaka Utama.

Atok, Hilmi. (2010). Aspek-aspek Percaya Diri. (Online) Tersedia: http://miklotof.wprdpress.com/20 10/06/26/aspek-aspek-percayadiri/ (19 Juli 2011).

Beers, M.H., \& Berkow, R. (2003). Mental retardation (Sec. 19, Chap. 262) [electronic version]. Merck manual of diagnosis and therapy. Retrieved on October 9, 2013, from www.merck.com/pubs/mmanual/s ection19/chapter262/262e.htm.

Center for Disease Control and Prevention. (2003, March). Childhood lead poisoning. Retrieved October 1, 2003.

Direktorat Pembinaan Sekolah Luar Biasa (2006). Identifikasi Anak Berkebutuhan Pendidikan Khusus dalam Pendidikan Inklusif, diambil dari http://www.ditplb.or.id/new/index .php?menu=profile \&pro=52.

Drew, C., \& Hardman, M. (2004). Mental retardation: A life cycle 
approach. Upper Saddle River, NJ: Pearson Education.

ERIC Clearinghouse on Disabilities and Gifted Education (2003, March). Prader-Willi syndrome. Retrieved October 9, 2003, from http://ericec.org/faq/praderwl.html

Fatimah, Enung. (2010). Psikologi

Perkembangan (Psikologi Perkembangan Peserta Didik). Bandung: CV Pustaka Setia. From www:cdc.gov/nceh/lead/factsheet s/childhoodlead.htm.

Greenspan, S., \& Love, P. (1997). Social intelligence and developmental disorder: Mental retardation, learning disabilities, and autism. In W. macLean (Ed.), Ellis handvook of mental deficiency, psychological of mental and research (3 ed., pp. 311-342). Marwah, NJ: Erlbaum.

Hakim, T. (2002).Mengatasi Rasa Tidak Percaya Diri. Jakarta: Purwa Suasana.

Hallahan, Daniel P. \& Kauffman, James M. (1938). Exceptional Children Introduction to Special Education New Jersey: Prentice International Inc.

Hitcock, D., Meyer, A., Rose, D., \& Jackson, R. (2002). Providing new access to the general curriculum Universal design for learning. Teaching Exceptional Children, 35 (2), 8-17.

Jenkins, J.R., Antil, L.R., Wayne, S.K., \& Vadasy, P.F. (2003). How cooperative learning works for special education and remedial students. Exceptional Children, 69, 279-292.
Katimas, D. (2000). Literacy Intruction for people with mental retardation: Historical highlights and contemporary anlysis. Education and Training in Mental Retardation and Developmental Disabilities, 35 (1), 3-15.

Lauster, Peter. (2008). Tes Kepribadian. Jakarta: PT. Bumi Askara.

March of Dimes. (2003). Quick reference; Birth defects and genetics-Down syndrome [fact sheet]. New York: National Down Syndrome Society. Retrieved October 8, 2003, from www.marchofdimes.com/printabl eArticles/681 1214.asp?printable $=$ true.

T. (Murro, J.J dan Kottman, 1995).Guidance and Counseling in The Elementary and Middle School. Madison: Wm C. Brown Com. Inc.

Nakata, H. (2003). Educational Cooperation Bases System Construction Project, Implementation Report, Center for Research on International Cooperation in National Down Syndrome Society. (2003, October). Questions and answers about Down Syndrome. Retrieved October 10, 2003, from www.ndss.org/content.cfm?fuseac tion=inforResGeneralArticle\&arti cle $=1994$.

Nayak, A. (1997). Guidance and Counseling. New Delhi: Aph Publishing Corporation.

Nurihsan, Juntika dan Sudianto, Akur.(2005). Manajemen Layanan Bimbingan dan Konseling di Jakarta.Jakarta : Grasindo. 
Nurihsan, Achmad Juntika. (2006). Bimbingan dan Konseling dalam Berbagai Latar Kehidupan. Bandung: PT. Refika Aditama.

Prayitno \& Amti (2009).Dasar-Dasar Bimbingan dan Konseling.Jakarta : Rineka Cipta.

Putra, Nusa (2011). Research and Development Penelitian dan Pengembangan suatu

Pengantar.Jakarta : Raja Grafindo Persada.

Rini, Jacinta F. (2002). Memupuk Rasa Percaya Diri. (Online). Tersedia: http://www.e-psikologi.com (9 April 2012).

Rustanto.(2009). Program Bimbingan Dan Konseling Remaja. Yogyakarta: Graha Ilmu.

Smith, J.D. (2003). Granting Monty's wish: From mental retardation to developmental disabilities. DDD Expres, 14 (1), 4.

Sugiyono.(2012). Metode Penelitian Kombinasi.Bandung : Alfabeta.

Sutisna. (2010). Peningkatan Kepercayaan Diri Siswa Melalui Strategi Layanan.

Sulaeman. (1984). Sumbangan Kecerdasan, Motivasi Berprestasi dan Kebiasaan Belajar dan Prestasi Belajar Akademik Para Siswa SMA di Jabar. Disertasi. Bandung SPS IKIP Bandung.

Spencer, V.G., \& Balboni, G. (2003). Can students with mental retardation teach their peers? Education and Training in Mental Retardation and Developmental Disabilities, 38, 32-61.

Symon, F.J., Clark, R.D., Roberts, J.P., \&Bailey, D.B. (2001).Classroom behavior of elementary schoolage boys with Fragile $\mathrm{X}$ syndrome.Journal of Special Education, 34, 194-202.

Symon, F.J., Clark, R.D., Roberts, J.P., \&Bailey, D.B. (2001).Classroom behavior of elementary schoolage boys with Fragile $\mathrm{X}$ syndrome.Journal of Special Education, 34, 194-202.

Tomporowski, P., \& Tinsley, V. (1997). Attention in mentally retarded persons. In W. Mac Lean (Ed.), Ellis' handbook of mental deficiency, psychological theory and research. Marwah, NJ: Erlbaum.

UU RI No. 20 Tahun (2003).Sitem Pendidikan Nasional. Bandung: Citra Umbara.

Willis, Sofyan S. (2004). Bimbingan Individu dan Praktek. Bandung: CV. Alfabeta.

Winkel, W.S. (1997). Bimbingan Konseling di Institusi Pendidikan. Jakarta: Gramedia.

Yusuf, Syamsu dan Nurihsan, Juntika.(2005). Landasan Bimbingan dan Konseling.Bandung: Remaja Rosdakarya.

Yusuf, Syamsu. (2006). Program Bimbingan dan Konseling di Sekolah. Bandung: Pustaka Bani Quraisy.

Yusuf, Syamsu L.N. (2009). Program Bimbingan dan Konseling di Sekolah. Bandung:Rizqi Pres 